\title{
Effects of structural complexity and habitat type on the gall distribution of Jatrophobia brasiliensis (Rübsaamen, 1907) (Diptera, Cecidomyiidae) in two host-species of Manihot (Euphorbiaceae)
}

\author{
Mariane S. Durães ${ }^{(}$, Walter S. de Araújo ${ }^{ \pm=(1)}$
}

Laboratório de Interações Ecológicas e Biodiversidade (LIEB), Departamento de Biologia Geral, Centro de Ciências Biológicas e da Saúde, Universidade Estadual de Montes Claros, Montes Claros, MG, Brazil.

表=-Corresponding author: walterbioaraujo@gmail.com

Edited by: Daniell R. R. Fernandes

Received: February 13, 2020. Accepted: March 11, 2020. Published: May 07, 2020.

\begin{abstract}
In the present study, we evaluate the distribution of galls induced by Jatrophobia brasiliensis (Rübsaamen, 1907) in two species of Manihot (Manihot caerulescens Pohl and Manihot sp.). The study was performed in two Cerrado phytophysiognomies (typical savannah and rocky savannah) in Jequitaí municipality, Minas Gerais, Brazil. A total of 1,157 galls of Jatrophobia brasiliensis were analyzed, of which 459 galls in Manihot sp. and 698 galls in Manihot caerulescens. We found that plant height, crown diameter and number of leaves per branch positively influenced the number of galled leaves. Our results also showed that habitat type influenced the number of galled leaves and the gall size, with the rocky savannah presenting more and larger galls than the typical savannah. Our findings demonstrate that both intrinsic (related to host plant structure) and extrinsic factors (related to habitat type) influence the distribution of the galls induced by Jatrophobia brasiliensis on Manihot.
\end{abstract}

Keywords: Cerrado, endophagous insects, environmental severity, mesic habitats, xeric habitats.

Galling insects are highly specialized herbivores capable of causing internal changes in the structure and physiology of plants for their own benefit, thus causing structures called galls (Stone \& Schönrogge 2003). Habitat characteristics can influence physiological conditions of host plants, and consequently, the distribution and success of galling insects (Fleck \& Fonseca 2007). Previous studies point a higher occurrence of insect galls in resident plants of xeric environments that are characterized by high stress levels caused by diverse environmental factors, as example, low water availability, high light incidence, low rainfall, and shallow layer of soils (Gonçalves-Alvim \& Fernandes 2001; Luz et al. 2012). In addition to habitat type, evidence indicates that the distribution and abundance of galling insects may be influenced by structural attributes of plants (review in Fleck \& Fonseca 2007). This is because structurally complex offer greater resource availability for insects (Araújo \& Santos 2009) and also tend to be better seen by insects during foraging, resulting in the induction of more galls.

In Brazil species of the genus Manihot (Euphorbiaceae) are distributed in the Cerrado and Caatinga (Neves et al. 2014), or ecotone savannah-forest (Duputié et al. 2011). Several wild species of the genus Manihot are attacked by the galling insect Jatrophobia brasiliensis (Rübsaamen, 1907) (Cecidomyiidae, Diptera), which is one of the most common in Manihot esculenta also (Scareli-Santos et al. 2018). Little is known about the relationship between this galling insect and the genus Manihot in wild environments. In this sense, the objective of this work was to evaluate the occurrence of galls induced by Jatrophobia brasiliensis in two species of Manihot and to test if the habitat type and the structural complexity of the host plant influenced the abundance and size of these galls.

The study was conducted in phytophysiognomies of Cerrado located in Jequitaí, northern Minas Gerais, Brazil. The region is located in the transition between the Cerrado and Caatinga biomes. Climate in the region is classified as Tropical Savanna Climate (Aw) according to Köppen classification, with dry winters and wet summers (Alvares et al. 2014). Mean annual precipitation is $1,000 \mathrm{~mm}$, with rains concentrated mainly from November to February, and mean annual temperature is $23.2^{\circ} \mathrm{C}$ (Alvares et al. 2014). Two areas were sampled, being that the first area $\left(80^{\circ} 93^{\prime} 85^{\prime \prime} \mathrm{S} ; 56^{\circ} 52^{\prime} 81^{\prime \prime} \mathrm{W}\right)$ is composed of typical savannah phytophysiognomy (sensu stricto cerrado) vegetation characterized by dense tree-shrub strata with plants with crooked, woody and sloping stems (Ribeiro \& Walter 2008). In the second area $\left(80^{\circ} 86^{\prime} 83^{\prime \prime}\right.$ S; $56^{\circ} 41^{\prime} 78^{\prime \prime} \mathrm{W}$ ) there is a rocky savannah phytophysiognomy (rocky sparce cerrado) that is characterized by open vegetation with the presence of rocky outcrops and dominated by a grassy stratum with few woody plants (Ribeiro \& Walter 2008). These two vegetations provide a natural gradient of vegetation complexity (typical savannah > rocky savannah) as well as environmental nutritional stress (rocky savannah $>$ typical savannah) to test hypotheses related to galling insect diversity (Gonçalves-Alvim \& Fernandes 2001).

Sampling was performed in two native species of genus Manihot: Manihot caerulescens Pohl and Manihot sp. Both species of Manihot are attacked by the galling insect Jatrophobia brasiliensis, which induces a green to brown cylindrical gall of approximately $3 \mathrm{~mm}$ in width and $8 \mathrm{~mm}$ in length. Insect gall sampling was performed on 18 plants from Manihot caerulescens and nine from Manihot $\mathrm{sp}$. selected in both phytophysiognomies. In each plant, were measured in the field the following characters: height $(\mathrm{m})$, stem circumference at ground level $(\mathrm{cm})$ and largest crown diameter $(\mathrm{m})$. Then, 10 apical branches of each individual were sampled and measured the number of leaves per branch, number of galled leaves and number of galls per branch (Araújo \& Santos 2009). In addition, the size (calculated as the product between height and width in $\mathrm{mm}$ ) of 10 randomly selected galls of each branch was measured using a caliper.

Generalized linear models (Dunn \& Smyth 2018) were constructed using the structural complexity variables of the host plant (height, crown diameter and number of leaves per branch), the type of phytophysiognomy (typical savannah and rocky savannah) and the plant species (Manihot caerulescens and Manihot sp.) as explanatory variables for the parameters of gall abundance and size (response 
variables). Explanatory variables used in the models were previously checked for multicollinearity using variance inflate factor (VIF). To compare the structural parameters between the two host species, mean comparison tests (t-test) were performed. All analyzes passed the assumption tests and were processed in the $\mathrm{R}$ software version 3.6.1 (R Development Core Team 2019).

A total of 1,157 galls of Jatrophobia brasiliensis were analyzed, of which 459 galls in Manihot sp. and 698 galls in Manihot caerulescens. The height of the host plants ranged from 0.4 to $2.8 \mathrm{~m}$ (average: $1.53 \pm$ 0.66 ). The largest crown diameter ranged from 0.2 to $4.0 \mathrm{~m}$ (average: $2.15 \pm 1.19$ ). The species Manihot caerulescens was taller than Manihot sp., but crown diameter and number of leaves per branch did not differ between the two species (Tab. 1). The two species of Manihot also had no differences in number of galls per branch, number of galled leaves and gall size (Tab. 2).

Among the structural variables analyzed, plant height, crown diameter and number of leaves per branch positively influenced the number of galled leaves (Tab. 2, Fig. 1). The positive relationship between structural complexity and number of leaves with galls may be due to galling insects using oviposition sites distributed throughout the entire length of the plant (Araújo \& Santos 2009). Our results are in agreement with the hypothesis that the higher offer of resources (number of leaves per branch, or broader crows) resulting in higher number of consumers (Faria \& Fernandes 2001).

The number of galled leaves was also significantly influenced by habitat type (Tab. 2), with the rocky savannah having more galls than the typical savannah (Fig. 2A). This result indicates the importance of environmental factors for the distribution of galling insects, as predicted by the hypothesis of hygrothermal stress (Fernandes \& Price 1992). In the case of the rocky savannah, as it is an environment with more severe environmental characteristics, due to the more open vegetation and the strong solar incidence, the plants are subjected to greater environmental stress (Gonçalves-Alvim \& Fernandes 2001). Thus, Manihot plants occurring in the rocky savannah (most stressed environment) accumulated a larger number of galls than host plants occurring in the typical savannah (least stressed environment). Our results corroborate previous studies with other Neotropical host plants indicating greater abundance of galls in xeric environments when compared to mesic environments (Ribeiro-Mendes et al. 2002; Coelho et al. 2012).

Gall size was affected by habitat type (Tab. 2), with plants of the rocky savannah having larger galls than plants of typical savannah (Fig. 2B), corroborating our expectations. Under stressed conditions the vegetation undergoes a series of modifications, such as overproduction of tannins and other defense compounds, which can positively affect the galling fauna (Fernandes \& Price 1992). In this context, our findings confirm previous studies that points that survival is higher for galling populations inhabiting xeric habitats compared with mesic habitats (e.g. Fernandes \& Price 1992; Gonçalves-Alvim \& Fernandes 2001; Luz et al. 2012).

Inventories of insect gall conducted in other Brazilian locations have recorded similar galls of Jatrophobia brasiliensis on Manihot. For example, Saito \& Urso-Guimarães (2012) recorded galls induced by Jatrophobia brasiliensis on Manihot caerulescens in phytophysiognomy of sensu stricto cerrado in the Brazilian Cerrado. In other study, Maia et al. (2008) recorded the same galls in an undetermined species of Manihot in restinga areas of the Atlantic Forest. The occurrence of Jatrophobia brasiliensis on host-species distributed by different Brazilian regions and biomes indicates that possibly this gall-inducer occurs throughout the distribution range of the genus Manihot. This gall-midge also occurs widely throughout Manihot esculenta crops, popularly called cassava, and is a major pest of these crops (ScareliSantos et al. 2018). Despite the importance of interactions involving this system, this is the first study that systematically investigated factors that influence the distribution of Jatrophobia brasiliensis galls on Manihot plants.

Our study suggests that both intrinsic factors related to host plant structure and extrinsic factors related to habitat type influence the distribution of Jatrophobia brasiliensis galls on Manihot. However, due to the spatial limitation of our study (which sampled only two locations), for a better understanding of these effects of Jatrophobia brasiliensis galls in Manihot, it would be necessary to expand the study spatially, with more replicates of the natural environments. In addition, due to the economic potential of the gall-midge attack on cassava

Table 1. Results of Student t-tests comparing the structural parameters of plants measured in two species of Manihot occurring in different Cerrado phytophysiognomies (sensu stricto cerrado and rocky savanna) from Northern Minas Gerais, Brazil.

\begin{tabular}{lccc}
\hline \multicolumn{1}{c}{ Response variables } & M. caerulescens (mean \pm SD) & Manihot sp. (mean \pm SD) & t-value \\
\hline Plant height $(\mathrm{m})$ & $1.778( \pm 0.671)$ & $1.047( \pm 0.232)$ & 4.152 \\
Crown diameter $(\mathrm{m})$ & $2.451( \pm 1.327)$ & $2.451( \pm 1.327)$ & 1.997 \\
Number of leaves per branch & $7.900( \pm 3.477)$ & $7.900( \pm 3.477)$ & 0.056 \\
\hline
\end{tabular}

Table 2. Generalized linear models to test the effects of habitat type and structural parameters on the abundance and size of galls observed on two Manihot species in different Cerrado phytophysiognomies (sensu stricto cerrado and rocky savanna) from Northern Minas Gerais, Brazil.

\begin{tabular}{|c|c|c|c|c|c|c|}
\hline Response variables & Explanatory variables & Deviance Resid. & Df & Resid. Dev & F-value & p-value \\
\hline \multirow[t]{5}{*}{ Number of galls per branch } & Habitat type & 29.9 & 25 & 200.2 & 3.510 & 0.075 \\
\hline & Species of Manihot & 0.2 & 24 & 200.0 & 0.021 & 0.884 \\
\hline & Plant height (m) & 2.7 & 23 & 197.4 & 0.3129 & 0.581 \\
\hline & Crown diameter $(\mathrm{m})$ & 1.4 & 22 & 196.0 & 0.1596 & 0.693 \\
\hline & Number of leaves per branch & 17.4 & 21 & 178.6 & 2.0452 & 0.167 \\
\hline \multirow[t]{5}{*}{ Number of galled leaves } & Habitat type & 102.8 & 25 & 1325.9 & 4.6302 & 0.043 \\
\hline & Species of Manihot & 14.5 & 24 & 1311.3 & 0.654 & 0.427 \\
\hline & Plant height (m) & 289.4 & 23 & 1021.9 & 13.033 & 0.001 \\
\hline & Crown diameter $(\mathrm{m})$ & 283.8 & 22 & 738.1 & 12.781 & 0.001 \\
\hline & Number of leaves per branch & 271.7 & 21 & 466.3 & 12.237 & 0.002 \\
\hline \multirow[t]{5}{*}{ Gall size } & Habitat type & 37420.0 & 25 & 59618.0 & 14.689 & 0.001 \\
\hline & Species of Manihot & 2412.0 & 24 & 57206.0 & 0.946 & 0.341 \\
\hline & Plant height (m) & 813.0 & 23 & 56394.0 & 0.319 & 0.578 \\
\hline & Crown diameter $(\mathrm{m})$ & 1047.0 & 22 & 55347.0 & 0.410 & 0.528 \\
\hline & Number of leaves per branch & 1850.0 & 21 & 53497.0 & 0.726 & 0.403 \\
\hline
\end{tabular}



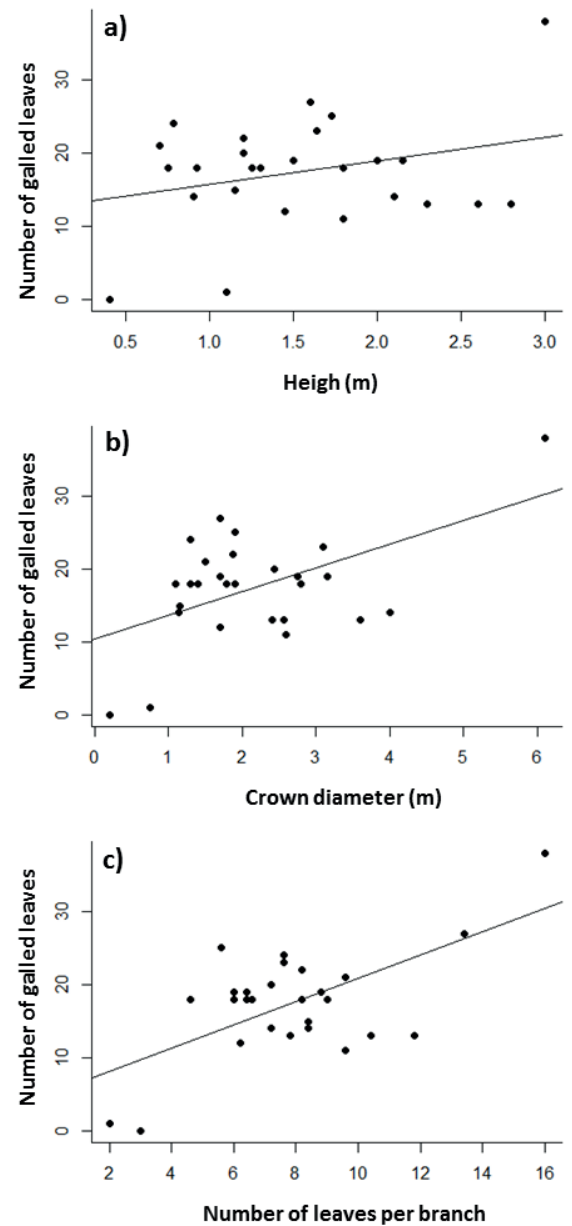

Figure 1. Relationship between the number of galled leaves with the structural parameters of plants: height (a), crown diameter (b) and number of leaves per branch (c) in two Manihot species in Cerrado phytophysiognomies (sensu stricto cerrado and rocky savanna) from Northern Minas Gerais, Brazil

Manihot esculenta, it would be interesting if studies also focused on agricultural environments. In this context, we suggest that future studies evaluate the effect of architectural and environmental drivers on the distribution of Jatrophobia brasiliensis simultaneously analyzing cultivated and wild Manihot species.

\section{Acknowledgments}

The authors would like to thank the PPGBURN-Unimontes and the Projeto Jequitaí CODEVASF/SEAPA-MG for logistical support during the fieldwork. The authors also thank gratefully to colleagues of LIEBUnimontes for help in the field sampling.

\section{Authors' Contributions}

M.S.D. and W.S.A. planned and conceived the sampling, discussed the results, and wrote the manuscript.

\section{References}

Alvares, C. A.; Stape, J. L.; Sentelhas, P. C.; Gonçalves, J. L. M.; Sparovek G. (2014) Koppen's climate classification map for Brazil. Meteorologische Zeitschrift, 22(6): 711-728. doi: 10.1127/09412948/2013/0507

Araújo, W. S.; Santos, B. B. (2009) Complexidade estrutural e diversidade de insetos galhadores em Styrax pohlii Fritsch (Styracaceae). Bioscience Journal, 25(3): 181-184.

Coelho, M. S.; Belmiro, M. S.; Santos, J. C.; Fernandes, G. W. (2012) Herbivory among habitats on the Neotropical tree Cnidoscolus quercifolius Pohl. in a seasonally deciduous forest. Brazilian Journal of Biology, 72(3): 453-457. doi: 10.1590/S1519-


Figure 2. Comparison of number of galled leaves (a) and gall size (b) in typical and rocky savannas of Northern Minas Gerais, Brazil. Comparison of the number of galled leaves (a) and gall size (b) between different Cerrado phytophysiognomies (sensu stricto cerrado and rocky savanna) from Northern Minas Gerais, Brazil.

\section{6}

Dunn, P. K.; Smyth, G. K. (2018) Generalized Linear Models with Examples in R. New York: Springer. doi:10.1007/978-1-4419-01187. ISBN 978-1-4419-0118-7.

Duputié, A.; Salick, J.; McKey, D. (2011) Evolutionary biogeography of Manihot (Euphorbiaceae), a rapidly radiating Neotropical genus restricted to dry environments. Journal of Biogeography, 38(6): 1033-1043. doi: 10.1111/j.1365-2699.2011.02474.x

Faria, M. L., Fernandes, G. W. (2001) Vigour of a dioecious shrub and attack by a galling herbivore. Ecological Entomology, 26(1), 37-45. doi: 10.1046/j.1365-2311.2001.00291.x

Fernandes, G. W.; Price, P. W. (1992) The adaptive significance of insect gall distribution: survivorship of species in xeric and mesic habitats. Oecologia, 90(1): 14-20. doi: 10.1007/BF00317803

Fleck. T.; Fonseca, C. R. (2007) Hypotheses for the richness of gall insects: a review considering the intraespecific, interespecific and community levels. Neotropical Biology and Conservation, 2(1): 3645.

Gonçalves-Alvim, S. J.; Fernandes, G. W. (2001) Biodiversity of galling insects: historical, community and habitat effects in four neotropical savannas. Biodiversity and Conservation, 10(1): 79-98. doi: 10.1023/A:1016602213305

Luz, G. R.; Fernandes, G. W.; Silva, J. O.; Neves, F. S.; Fagundes, M. (2012) Insect galls in xeric and mesic habitats in a Cerrado-Caatinga transition in northern Minas Gerais, Brazil. Neotropical Biology and Conservation, 7(3): 171-187. doi: 10.4013/nbc.2012.73.04

Maia, V. C.; Magenta, M. A. G.; Martins, S. E. (2008) Ocorrência e caracterização de galhas de insetos em áreas de restinga de Bertioga (São Paulo, Brasil). Biota Neotropica, 8(1), 167-197. doi: 10.1590/S1676-06032008000100020

Neves, R. J.; Carvalho, P. C. L.; Alves, A. A. C., Ledo, C. A. S.; Martins, 
M. L. L. (2014) Wild Species of Manihot Mill. (Euphorbiaceae) in the Embrapa Cassava and Fruit Collection, Cruz das Almas, Bahia, Brazil. Iheringia Série Botanica, 69(2): 245-256.

R Development Core Team (2019) R: A Language and Environment for Statistical Computing. R Foundation for Statistical Computing, Vienna. https://www.r-project.org/

Ribeiro, J. F.; Walter, B. M. T. (2008) As principais fitofisionomias do bioma Cerrado. In: Sano, S. M.; Almeida, S. P.; Ribeiro J. F. (Eds.), Cerrado: ecologia e flora, pp. 151-212. Brasília: Embrapa Cerrados.

Ribeiro-Mendes, H. N.; Marques, E. S. A.; Silva, I. M.; Fernandes, G. W. (2002) Influence of host-plant sex and habitat on survivorship of insect galls within the geographical range of the host-plant. Tropical Zoology, 15(1): 5-15. doi: 10.1080/03946975.2002.10531163

Saito, V. S.; Urso-Guimarães, M. V. (2012) Characterization of galls, insect galls and associated fauna of Ecological Station of Jataí (Luiz Antônio, SP). Biota Neotropica, 12(3): 99-107. doi: 10.1590/S167606032012000300011

Scareli-Santos, C.; Silva, P.; Carneiro, A.; Dantas, S. (2018) Infestação por galhas em Manihot esculenta Crantz (Euphorbiaceae): Avaliação dos impactos na arquitetura e na produtividade da planta hospedeira. Revista Desafios, 5(2): 1-9. doi: 10.20873/uft.23593652.2018vol5n2p51

Stone, G. N.; Schönrogge, K. (2003) The adaptive significance of insect gall morphology. Trends in Ecology and Evolution, 18(10): 512-522. doi: 10.1016/S0169-5347(03)00247-7 